\title{
DNA interactions and biocidal activity of metal complexes of benzothiazole Schiff bases: synthesis, characterization and validation
}

\author{
NARENDRULA VAMSIKRISHNA, MARRI PRADEEP KUMAR, GALI RAMESH, \\ NIRMALA GANJI, SREENU DARAVATH and SHIVARAJ* \\ Department of Chemistry, Osmania University, Hyderabad, Telangana 500 007, India \\ E-mail: shivaraj_sunny@yahoo.co.in
}

MS received 25 November 2016; revised 27 March 2017; accepted 27 March 2017

\begin{abstract}
Binary complexes of $\mathrm{Cu}(\mathrm{II}), \mathrm{Ni}(\mathrm{II})$ and $\mathrm{Co}(\mathrm{II})$ were synthesized using two novel Schiff bases $\mathbf{L}_{1}=$ 2-(-(benzothiazol-6-ylimino)methyl)-4-chlorophenol (BTEMCP), $\mathbf{L}_{2}=$ 2-(-(benzothiazol-6-ylimino) methyl)-4-nitrophenol. The Schiff bases and metal complexes were characterized by analytical and spectral methods like elemental analysis, Mass, ${ }^{1} \mathrm{H}-\mathrm{NMR},{ }^{13} \mathrm{C}-\mathrm{NMR}$, UV-Vis, IR, ESR, SEM, EDX, XRD and magnetic susceptibility measurements. From the analytical data, square planar geometry has been proposed for all the metal complexes. The binding interaction between the metal complexes and DNA was investigated by means of electronic absorption, fluorescence spectroscopy and viscosity measurements. The DNA cleavage ability of the metal complexes was also evaluated by agarose gel electrophoresis method. These studies revealed that the complexes showed an intercalative mode of binding to CT DNA and also effectively cleaved the supercoiled pBR DNA. The synthesised compounds were evaluated for in vitro antibacterial activity against Gram positive and Gram negative bacteria, and found that the metal complexes showed more potent biocidal activity than the Schiff bases.
\end{abstract}

Keywords. Schiff base; binary complex; DNA binding cleavage; fluorescence; viscosity.

\section{Introduction}

In recent years, the study of interactions between transition metal complexes of Schiff base and DNA have gained much attention due to their possible applications in cancer therapy ${ }^{1-3}$ and molecular biology. ${ }^{4-6}$ DNA is the primary target molecule of many anticancer agents, and the binding between DNA and metal complexes were used in understanding the interaction between the drugs and DNA. In general, the tumour cells can be smashed by stopping the replication of the unnatural DNA. Using Schiff base transition metal complex in particular, affected DNA may be dented by either following cleavage or binding approach. Transition metal complexes can bind to DNA through the noncovalent way on the groove, by intercalation and electrostatic binding. ${ }^{7}$ From the literature survey, we find that a vast number of metal complexes have been used as cleavage agents for DNA. Metal complexes can cleave the DNA through three types of mechanisms, which are hydrolytic, oxidative and photolytic cleavages. ${ }^{8-10}$ Cisplatin and its second generation com-

\footnotetext{
*For correspondence
}

pounds are the most widely used metal-based drugs for cancer treatment. However cisplatin, oxaliplatin and carboplatin possess inherent limitations such as resistance, toxicity and other side effects. ${ }^{11,12}$ To overcome these short comings of cisplatin derivatives, and to design less toxic, cheaper and non-covalently bound new chemotherapeutic drugs, the focus has been shifted to the Schiff bases containing transition metal complexes. Schiff bases derived from benzothiazole compounds have attracted a great deal of interest due to their biological and pharmacological properties such as antiHIV, antitubercular, anti-inflammatory, anticonvulsant, antileishmanial, antimalarial, analgesic, antimicrobial, lipid peroxidation inhibitor and anticancer. ${ }^{13-19} \mathrm{Cu}$ (II) complexes act as best alternatives to platinum based antitumor agents. ${ }^{20,21}$ Cytotoxicity of $\mathrm{Cu}(\mathrm{II})$ complexes is mainly due to their ability to bind and cleave DNA which leads to cell cycle prevention and apoptosis. ${ }^{22-24}$ The numerous reports have also narrated the reactivity of DNA with mononuclear Ni(II) complexes. ${ }^{25}$ The chemistry of $\mathrm{Ni}(\mathrm{II})$ complexes with Schiff base ligands may provide the origin for models of the active sites of biological systems or to act as catalysts. ${ }^{26}$ Cobalt complexes have gained importance for their 
applicability in the biological field. ${ }^{27,28}$ Some Co(II) complexes such as hexamine cobalt induced DNA condensation. ${ }^{29}$ DNA interactions and antimicrobial studies of binary metal complexes of isoxazole and benzothiazole Schiff bases were reported earlier from our laboratory. ${ }^{30-32}$

In view of the above facts, herein, we report the synthesis, characterization, DNA binding, cleavage and antibacterial activity of $\mathrm{Cu}(\mathrm{II}), \mathrm{Ni}(\mathrm{II})$ and $\mathrm{Co}(\mathrm{II})$ complexes containing benzothiazole Schiff bases.

\section{Experimental}

\subsection{Materials}

The ligand precursors 6-amino benzothiazole, 5-chloro salicylaldehyde/5-nitro salicylaldehyde and all metal salts used for the preparation of metal complexes were purchased from Sigma-Aldrich Bangalore, India. The solvents methanol, petroleum ether, chloroform, DMF and DMSO were used after purification by the standard methods described in the literature. The CT-DNA (Product number of CTDNA is 615100780041730) and supercoiled pBR322 DNA were procured from Genei, Bangalore and stored at $4^{\circ} \mathrm{C}$. Tris- $\mathrm{HCl} / \mathrm{NaCl}$ buffer, ethidium bromide were obtained from Merck, Hyderabad, India.

\subsection{Instrumentation}

The elemental analysis $(\mathrm{C}, \mathrm{H}, \mathrm{N}, \mathrm{S})$ of the compounds was carried out on a Perkin Elmer 240C (USA) elemental analyzer. Melting points of the compounds were determined with open glass capillary tubes on a Polmon instrument (Model No. MP-96). Metal content of the complexes was estimated by atomic absorption spectroscopy using GBC Avanta 1.0 AAS. NMR spectra of all the synthesized ligands were recorded in $\mathrm{CDCl}_{3} /$ Deuterated DMSO using TMS as an internal standard reference on a Bruker $400 \mathrm{MHz}$ spectrometer. Scanning electron micrography (on Zeiss scanning electron microscope) with associated energy dispersive spectrometry (on INCA EDX instrument) were used for morphological evaluation. ESI mass spectra were obtained on a Vergleichbare Gerate (VG) micromass 7070$\mathrm{H}$ instrument. Infrared spectra of the ligand and the metal complexes were recorded in the range of $4000-400 \mathrm{~cm}^{-1}$ using a Perkin-Elmer Infrared Model 337 spectrophotometer using $\mathrm{KBr}$ discs. Electronic spectra of the complexes were recorded on a Shimadzu Model 1601 UV-Vis Spectrophotometer in the wavelength range of 200-800 nm using DMSO as solvent. Shimadzu RF-5301PC Spectrofluorometer was used to record the fluorescence spectra of the compounds. Effective magnetic moments of the complexes were determined on a Guoy balance Model 7550 using $\mathrm{Hg}\left[\mathrm{Co}(\mathrm{NCS})_{4}\right]$ as standard. The thermogravimetric analysis was carried out in dynamic nitrogen atmosphere with a heating rate of $10^{\circ} \mathrm{C} \mathrm{min}^{-1}$ using Mettler Toledo Star system in the temperature range of $30-1000^{\circ} \mathrm{C}$. EPR spectra of the $\mathrm{Cu}$ (II) complexes were recorded using JES-FA 200 ESR spectrometer (JEOL-Japan) at liquid nitrogen temperature (77K).

\subsection{Synthesis of Schiff bases}

Hot methanolic soluations of 6-aminobenzothiazole (10 mM) and 5-chlorosalicylaldehyde ( $10 \mathrm{mM}) / 5$-nitrosalicylaldehyde $(10 \mathrm{mM})$ were mixed and refluxed on an oil bath for $4 \mathrm{~h}$ with constant stirring. The resulting solid product was isolated by filtration and recrystallized from hot methanol.

2.3a Ligand $\mathbf{L}_{1}$ : M.p.: $180^{\circ} \mathrm{C} ; \mathrm{C}_{14} \mathrm{H}_{9} \mathrm{ClN}_{2} \mathrm{OS}$ : Anal. Found: C, 58.03; H, 3.18; N, 9.70; S, 11.15\% Calc.: C, $58.23 ; \mathrm{H}, 3.14 ; \mathrm{N}, 9.70 ; \mathrm{S}, 11.10 \%$. IR $\left(\mathrm{KBr}, \nu / \mathrm{cm}^{-1}\right)$ : $\left(\nu_{\mathrm{O}-\mathrm{H}}\right) 3434,\left(\nu_{\mathrm{CH}=\mathrm{N}}\right) 1620,\left(\nu_{\mathrm{C}-\mathrm{O}}\right) 1163$. UV-Vis (DMSO) $\lambda_{\max } / \mathrm{nm}\left(\varepsilon / \mathrm{M}^{-1} \mathrm{~cm}^{-1}\right): 258$ (38760), 300 (33333). ESI-MS (m/z): Calc.: 288: Found: 289. ${ }^{1} \mathrm{H}-\mathrm{NMR}\left(400 \mathrm{MHz}, \mathrm{CDCl}_{3}\right.$, TMS): $\delta 13.0(\mathrm{~s}, 1 \mathrm{H}) ; 9.01(\mathrm{~s}, 1 \mathrm{H}) ; 8.60(\mathrm{~s}, 1 \mathrm{H}) ; 8.16(\mathrm{~d}, 1 \mathrm{H})$; $7.83(\mathrm{~s}, 1 \mathrm{H}) ; 7.46-7.18(\mathrm{~m}, 3 \mathrm{H}) ; 6.98(\mathrm{~d}, \mathrm{H})$ (Figure $\mathrm{S} 1$ in Supplementary Information). ${ }^{13} \mathrm{C}$ NMR $\left(100 \mathrm{MHz}, \mathrm{CDCl}_{3}\right.$ TMSO): $\delta 161.7$ 159.6, 154.5, 152.4, 145.7, 135.0, 133.3, 131.3, 124.3, 123.8, 120.1, 119.8, 118.9, 114.4.

2.3b Ligand $\mathbf{L}_{2}$ : M.p.: $195^{\circ} \mathrm{C} ; \mathrm{C}_{14} \mathrm{H}_{9} \mathrm{~N}_{3} \mathrm{O}_{3} \mathrm{~S}$ : Anal. Found: C, 56.14; H, 3.06; N, 14.08; S, 10.74\%. Calc.: C, $56.18 ; \mathrm{H}, 3.03 ; \mathrm{N}, 14.04 ; \mathrm{S}, 10.71 \%$. IR $\left(\mathrm{KBr}, v / \mathrm{cm}^{-1}\right)$ : $\left(v_{\mathrm{O}-\mathrm{H}}\right) 3430,\left(v_{\mathrm{CH}=\mathrm{N}}\right) 1625,\left(\nu_{\mathrm{C}-\mathrm{O}}\right) 1160 . \mathrm{UV}-\mathrm{Vis}(\mathrm{DMSO})$ $\lambda_{\max } / \mathrm{nm}\left(\varepsilon / \mathrm{M}^{-1} \mathrm{~cm}^{-1}\right): 256$ (39062), 308 (32467). ESI-MS (m/z): Calc.: 299. Found: $300(\mathrm{M}+1) .{ }^{1} \mathrm{H}-\mathrm{NMR}(400 \mathrm{MHz}$, $\left.\mathrm{CDCl}_{3}, \mathrm{TMS}\right): \delta 14.17(\mathrm{~s}, 1 \mathrm{H}) ; 9.433(\mathrm{~s}, 1 \mathrm{H}) ; 9.238(\mathrm{~s}, 1 \mathrm{H})$; 8.296-8.016 (m, 3H) $7.726(\mathrm{~s}, 1 \mathrm{H}) ; 7.168(\mathrm{~s}, 1 \mathrm{H}) . \mathrm{C}^{13}-\mathrm{NMR}$ (100 MHz, $\mathrm{CDCl}_{3}$ TMSO): $\delta 166.1,161.6,157.0,152.2$, $144.5,139.3,134.8,128.0,127.9,123.6,120.2,118.9,118.1$, 115.3 .

\subsection{Synthesis of metal complexes}

To a hot methanolic solution of the Schiff base [2-(-(benzo [d]thiazol-6-ylimino)methyl)-4-chlorophenol/2-(-(benzo[d] thiazol-6-ylimino)methyl)-4-nitrophenol] (10 mmol), a solution of metal(II) acetate of copper, nickel or cobalt (10 mmol) in hot methanol was added drop wise and the resulting mixture was refluxed for $2-4 \mathrm{~h}$, kept reaction in basic condition. The solid product obtained was separated, washed thoroughly with methanol and dried in vacuum.

2.4a $\left[C u(B T E M C P)_{2}\right](1): \quad$ M.p.: $265^{\circ} \mathrm{C} ; \mathrm{C}_{28} \mathrm{H}_{16} \mathrm{Cl}_{2}$ $\mathrm{N}_{4} \mathrm{O}_{2} \mathrm{~S}_{2} \mathrm{Cu}$ : Anal. Found: $\mathrm{C}, 52.65 ; \mathrm{H}, 2.50 ; \mathrm{N}, 8.80 ; \mathrm{S}$, 10.06. Cu; 9.92\%. Calc.: C, 52.63; H, 2.52; N, 8.77; S, 10.04; $\mathrm{Cu}, 9.94 \%$. IR $\left(\mathrm{KBr}, \nu / \mathrm{cm}^{-1}\right): v_{(\mathrm{CH}=\mathrm{N})} 1602, \nu_{(\mathrm{C}-\mathrm{O})} 1176$, $v_{(\mathrm{M}-\mathrm{O})} 530, \quad \nu_{(\mathrm{M}-\mathrm{N})} 450$. UV-Vis $\quad$ (DMSO) $\lambda_{\max } / \mathrm{nm}$ $\left(\varepsilon / \mathrm{M}^{-1} \mathrm{~cm}^{-1}\right): 265$ (37735), 400 (25000), 570 (17547). ESR: $\mathrm{g}_{\|}=2.15, \mathrm{~g}_{\perp}=2.09, \mathrm{G}=1.53$. $\mu_{\mathrm{eff}}(\mathrm{BM}): 1.82$. ESIMS (m/z): Calc.: 636. Found: $659[\mathrm{M}+\mathrm{Na}]^{+}$. 
2.4b [Ni(BTEMCP $\left.)_{2}\right]\left(\right.$ 2): M.p.: $310^{\circ} \mathrm{C} ; \mathrm{C}_{28} \mathrm{H}_{16} \mathrm{Cl}_{2}$ $\mathrm{N}_{4} \mathrm{O}_{2} \mathrm{~S}_{2} \mathrm{Ni}$ : Anal. Found: C, 53.05; H, 2.50; N, 8.85; S, 10.12; Ni, 9.21\%. Calc.: C, 53.03; H, 2.54; N, 8.83; S, $10.11 ; \mathrm{Ni}, 9.25 \%$. IR $\left(\mathrm{KBr}, v / \mathrm{cm}^{-1}\right): v_{(\mathrm{CH}=\mathrm{N})} 1605, \nu_{(\mathrm{C}-\mathrm{O})}$ $1180, v_{(M-O)} 520, v_{(M-N)} 437$. UV-Vis (DMSO) $\lambda_{\max } / \mathrm{nm}$ $\left(\varepsilon / \mathrm{M}^{-1} \mathrm{~cm}^{-1}\right): 280$ (35714), 411 (24330), 564 (17667). ESIMS (m/z): Calc.: 631; Found: $670[\mathrm{M}+\mathrm{K}]^{+}$.

2.4c [Co $\left.(\text { BTEMCP })_{2}\right](3): \quad$ M.p.:280 ${ }^{\circ} \mathrm{C} ; \mathrm{C}_{28} \mathrm{H}_{16} \mathrm{Cl}_{2}$ $\mathrm{N}_{4} \mathrm{O}_{2} \mathrm{~S}_{2} \mathrm{Co}$ : Anal. Found: C, 53.05; H, 2.56; N, 8.85; S, 10.12; Co $9.25 \%$ Calc: C, 53.01; H, 2.54; N, 8.83; S, 10.11; Co, 9.29\%. IR (KBr): $v_{(\mathrm{CH}=\mathrm{N})} 1600, v_{(\mathrm{C}-\mathrm{O})} 1179, v_{(\mathrm{M}-\mathrm{O})} 532$, $\nu_{(\mathrm{M}-\mathrm{N})}$ 429. UV-Vis (DMSO) $\lambda_{\max } / \mathrm{nm}\left(\varepsilon / \mathrm{M}^{-1} \mathrm{~cm}^{-1}\right): 259$ (38610), 410 (24390), 550 (19011). $\mu_{\text {eff }}$ (BM): 2.14. ESI-MS $(\mathrm{m} / \mathrm{z})$ : Calc.: 632 . Found: $655[\mathrm{M}+\mathrm{Na}]^{+}$.

$2.4 \mathrm{~d} \quad\left[C u(B T E M N P)_{2}\right](4): \quad$ M.p.: $290^{\circ} \mathrm{C} ; \mathrm{C}_{28} \mathrm{H}_{16} \mathrm{~N}_{6}$ $\mathrm{O}_{6} \mathrm{~S}_{2} \mathrm{Cu}$ : Anal. Found: $\mathrm{C}, 50.92 ; \mathrm{H}, 2.42 ; \mathrm{N}, 12.69 ; \mathrm{S}, 9.68$; $\mathrm{Cu}, 9.60 \%$. Calc.: C, 50.94; H, 2.44; N, 12.73; S, 9.71; $\mathrm{Cu}, 9.63 \%$. IR $\left(\mathrm{KBr}, \nu / \mathrm{cm}^{-1}\right): v_{(\mathrm{CH}=\mathrm{N})} 1609, v_{(\mathrm{C}-\mathrm{O})} 1182$, $v_{(\mathrm{M}-\mathrm{O})} 515, v_{(\mathrm{M}-\mathrm{N})}$ 426. ESR: $\mathrm{g}_{\|}=2.12, \mathrm{~g}_{\perp}=2.07$, $\mathrm{G}=1.61$. UV-Vis (DMSO) $\lambda_{\max } / \mathrm{nm}\left(\varepsilon / \mathrm{M}^{-1} \mathrm{~cm}^{-1}\right): 260$ (38462), 442 (22624), 538 (18587). $\mu_{\text {eff }}(\mathrm{BM}): 1.72$. ESI-MS (m/z): Calc.: 659. Found: $698[\mathrm{M}+\mathrm{K}]^{+}$.

2.4e $\quad\left[N i(B T E M N P)_{2}\right](5): \quad$ M.p.:315 ${ }^{\circ} \mathrm{C} ; \mathrm{C}_{28} \mathrm{H}_{16} \mathrm{~N}_{6}$ $\mathrm{O}_{6} \mathrm{~S}_{2} \mathrm{Ni}$ : Anal. Found: $\mathrm{C}, 51.30 ; \mathrm{H}, 2.44 ; \mathrm{N}, 12.79 ; \mathrm{S}, 9.76 ; \mathrm{Ni}$ 8.93\%. Calc.: C, 51.32; H, 2.46; N, 12.82; S, 9.79; Ni, 8.96\%. IR $\left(\mathrm{KBr}, \nu / \mathrm{cm}^{-1}\right): \nu_{(\mathrm{CH}=\mathrm{N})} 1608, \nu_{(\mathrm{C}-\mathrm{O})} 1173, \nu_{(\mathrm{M}-\mathrm{O})} 545$, $\nu_{(\mathrm{M}-\mathrm{N})}$ 430. UV-Vis (DMSO) $\lambda_{\max } / \mathrm{nm}\left(\varepsilon / \mathrm{M}^{-1} \mathrm{~cm}^{-1}\right): 260$ (38461), 410 (24390), 526 (19011). ESI-MS (m/z): Calc.: 653. Found: $653[\mathrm{M}]^{+}$.

2.4f $\left[C o(B T E M N P)_{2}\right](6): \quad$ M.p.: $300^{\circ} \mathrm{C} ; \mathrm{C}_{28} \mathrm{H}_{16} \mathrm{~N}_{6}$ $\mathrm{O}_{6} \mathrm{~S}_{2} \mathrm{C}$ : Anal. Found: C, 51.32; H, 2.48; N, 12.80; S, 9.80; Co, 8.9\%. Calc.: C, 51.30; H, 2.46; N, 12.82; S, 9.78; Co, 8.99\%. IR $\left(\mathrm{KBr}, \nu / \mathrm{cm}^{-1}\right) \nu_{(\mathrm{CH}=\mathrm{N})} 1598, \nu_{(\mathrm{C}-\mathrm{O})} 1170, \nu_{(\mathrm{M}-\mathrm{O})} 503$, $\nu_{(\mathrm{M}-\mathrm{N})} 415$; UV-Vis (DMSO) $\lambda_{\max } / \mathrm{nm}\left(\varepsilon / \mathrm{M}^{-1} \mathrm{~cm}^{-1}\right): 262$ (38168), 411(24330), 556 (17985). $\mu_{\text {eff }}(\mathrm{BM}): 2.16$. ESI-MS (m/z): Calc.: 654; Found: $693[\mathrm{M}+\mathrm{K}]^{+}$.

\subsection{DNA binding studies}

2.5a Electronic absorption spectroscopic studies: The UV-Vis titration experiments were performed by maintaining a constant concentration of the complexes at $10 \mu \mathrm{M}$ throughout experiment ( $5 \mathrm{mM}$ Tris- $\mathrm{HCl} / 50 \mathrm{mM} \mathrm{NaCl}$ buffer at $\mathrm{pH}$ 7.4). The ratio of $1.8-1.9$ of $\mathrm{UV}$ absorbance at 260 and $280 \mathrm{~nm}$ was given by CT-DNA in tris $\mathrm{HCl}-\mathrm{NaCl}$ buffer solution, indicating that the DNA was sufficiently free of protein. ${ }^{33}$ The concentration of the source DNA is $1 \mathrm{mg} / \mathrm{mL}$. We determined the concentration of CT-DNA stock solution by employing a molar absorptivity $\left(6600 \mathrm{M}^{-1} \mathrm{~cm}^{-1}\right)$ at $\mathrm{A}_{260} \mathrm{~nm},{ }^{34}$ after 1:30 dilution of source DNA with $5 \mathrm{mM}$ Tris- $\mathrm{HCl} / 50 \mathrm{mM} \mathrm{NaCl}$ buffer at $\mathrm{pH}=7.2$. Thus, the concentration of the source DNA $(1 \mathrm{mg} / \mathrm{mL})$ is estimated to be $5700 \mu \mathrm{M}$. In experiments, the concentration of CT-DNA was varied between $0-10 \mu \mathrm{M}$ keeping the total volume of the reaction mixture constant $(3 \mathrm{~mL})$. After each addition of CT-DNA to the complex, the resulting solution was allowed to equilibrate at $25^{\circ} \mathrm{C}$ for 5 min followed by recording of absorption spectrum. The binding constants $\left(\mathrm{K}_{\mathrm{b}}\right)$ were calculated from the spectroscopic titration data by the plot between $[\mathrm{DNA}] /\left(\varepsilon_{\mathrm{a}}-\varepsilon_{\mathrm{f}}\right)$ and [DNA]. ${ }^{35}$

2.5b Fluorescence study: Further support for the binding of complexes to DNA was given through the fluorescence quenching study. A mixture of the CT-DNA $(125 \mu \mathrm{M})$ and ethidium bromide (EB) $(12.5 \mu \mathrm{M})$ was subjected to competitive binding with increasing amount of complex $(0-60 \mu \mathrm{M})$. The DNA bound EB/complexes was excited at $350 \mathrm{~nm}$. The binding constants $\mathrm{K}_{\mathrm{b}}\left(=\mathrm{K}_{\mathrm{sv}}\right)$ were calculated using following equation and observed the changes of fluorescence intensity with increasing concentration of quencher (complex).

$$
\mathrm{I}_{0} / \mathrm{I}=1+\mathrm{K}_{\mathrm{SV}} \mathrm{r}
$$

Where, $\mathrm{I}_{0}$ and I are the fluorescence intensities in the absence and presence of complexes respectively, $\mathrm{K}_{\mathrm{SV}}$ is a well-known linear Stern-Volmer constant, and $r$ is the concentration of the quencher (complex).

2.5c Viscosity study: Viscosity experiments were carried out on an Ostwald's viscometer, immersed in a thermostatic water bath at constant temperature $\left(30 \pm 1^{\circ} \mathrm{C}\right)$. Concentration of metal complexes was varied $(0-100 \mu \mathrm{M})$ and concentration of DNA $(100 \mu \mathrm{M})$ was kept constant. Flow time was recorded with a digital stopwatch for three times of each sample and an average flow time was calculated.Data are presented as plot of $\left(\eta / \eta_{0}\right)^{1 / 3}$ versus [complexes]/[DNA], where $\eta_{0}$ is the viscosity of DNA alone and $\eta$ is the viscosity of DNA in the presence of complex.

\subsection{DNA cleavage}

Interaction between pBR322 plasmid DNA and complexes were examined by gel electrophoresis experiments. The complexes were moving on agarose gel under the influence of electric field. The stock solutions of complexes in DMSO were prepared and used freshly. The experiment involves incubating the samples $(20 \mu \mathrm{M})$ with pBR322 plasmid DNA $(0.2 \mu \mathrm{g} / \mu \mathrm{L})$ in tris- $\mathrm{HCl} / \mathrm{NaCl}$ buffer $(\mathrm{pH} 7.2)$ at $37^{\circ} \mathrm{C}$ for 2 $\mathrm{h}$. The gel was then blemished using ethidium bromide (EB) and photographed under UV light. All the experiments were performed at room temperature.

\subsection{Antibacterial assay}

All the ligands and complexes were screened against Pseudomonas aeruginosa, Escherichia coli, Staphylococcus aureus and Bacillus subtilis for antibacterial activity. The tests were performed using the disc diffusion method. All the stock solutions were prepared by dissolving compounds in DMSO. The test microorganisms were grown on nutrient agar medium in 
<smiles>Nc1ccc2ncsc2c1</smiles><smiles>[R]c1ccc(O)c(C=O)c1</smiles><smiles>[R]Oc1ccc(O)c(/C=N/c2ccc3ncsc3c2)c1</smiles>

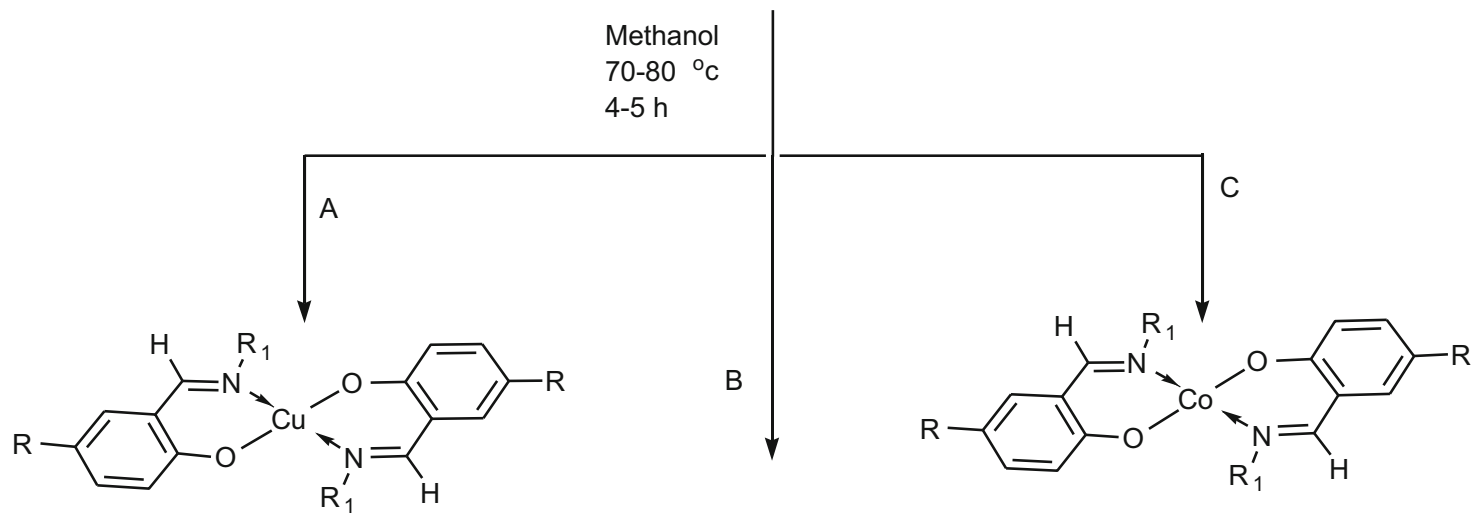<smiles></smiles>

$\mathrm{R}=\mathrm{Cl} 1,2 \& 3$ complexes

$\mathrm{R}=\mathrm{NO}_{2} \quad 4,5$ \& 6 complexes<smiles>[R]=C=Nc1ccc(C)cc1</smiles>

Scheme 1. Synthesis of ligands and their metal complexes.

Petri plates. The compounds were soaked in a filter paper disk of $1 \mathrm{~mm}$ thickness and $5 \mathrm{~mm}$ diameter. The discs were placed on Petri plates and incubated at $37^{\circ} \mathrm{C}$. The diameter of inhibition zone around each disc was measured after $24 \mathrm{~h}$.

\section{Results and Discussion}

\subsection{FT-IR spectroscopy}

The IR spectra of ligands $\mathbf{L}_{1}$ and $\mathbf{L}_{2}$ showed sharp peaks at 1620 and $1625 \mathrm{~cm}^{-1}$, respectively (Figure S2 in Supplementary Information), which corresponds to azomethine $(-\mathrm{C}=\mathrm{N})$ group. These peaks are shifted to lower frequency by 18 to $20 \mathrm{~cm}^{-1}$ due to coordination of nitrogen of azomethine to the metal ion. ${ }^{36,37}$ The broad band at 3434 and $3430 \mathrm{~cm}^{-1}$ due to $-\mathrm{OH}$ group of in metal-free ligands $\left(\mathbf{L}_{1}\right.$ and $\left.\mathbf{L}_{2}\right)$ disappeared in the metal complexes (1-6). A medium intensity band which showed at 1160 and $1163 \mathrm{~cm}^{-1}$ due to phenolic $\mathrm{C}-\mathrm{O}$ group of the ligands $\mathbf{L}_{1}$ and $\mathbf{L}_{2}$ are shifted towards positive side by $15-25 \mathrm{~cm}^{-138}$ upon complexation. The formation of complexes is further confirmed by the new bands observed at lower frequency region 415450 and $515-545 \mathrm{~cm}^{-1}, 39,40$ respectively due to $\mathrm{M}-\mathrm{N}$ 
Table 1. Some important IR absorption frequencies $\left(\mathrm{cm}^{-1}\right)$ of Schiff bases and their $\mathrm{Cu}(\mathrm{II}), \mathrm{Ni}(\mathrm{II})$ and $\mathrm{Co}(\mathrm{II})$ complexes

\begin{tabular}{llllll}
\hline Compound & $v(\mathrm{O}-\mathrm{H})$ & $v(\mathrm{CH}=\mathrm{N})$ & $v(\mathrm{C}-\mathrm{O})$ & $v(\mathrm{M}-\mathrm{O})$ & $v(\mathrm{M}-\mathrm{N})$ \\
\hline $\mathrm{BTEMCP}\left(\mathbf{L}_{1}\right)$ & 3434 & 1620 & 1163 & - & - \\
{$\left[\mathrm{Cu}(\mathrm{BTEMCP})_{2}\right](\mathbf{1})$} & - & 1602 & 1176 & 530 & 450 \\
{$\left[\mathrm{Ni}(\mathrm{BTEMCP})_{2}\right](\mathbf{2})$} & - & 1605 & 1180 & 520 & 437 \\
{$\left[\mathrm{Co}(\mathrm{BTEMCP})_{2}\right](\mathbf{3})$} & - & 1600 & 1179 & 532 & 429 \\
$\mathrm{BTEMNP}\left(\mathbf{L}_{2}\right)$ & 3430 & 1625 & 1160 & - & - \\
{$\left[\mathrm{Cu}(\mathrm{BTEMNP})_{2}\right](\mathbf{4})$} & - & 1609 & 1182 & 515 & 426 \\
{$\left[\mathrm{Ni}(\mathrm{BTEMNP})_{2}\right](\mathbf{5})$} & - & 1608 & 1173 & 545 & 430 \\
{$\left[\mathrm{Co}(\mathrm{BTEMNP})_{2}\right](\mathbf{6})$} & - & 1598 & 1170 & 503 & 415 \\
\hline
\end{tabular}

and $\mathrm{M}-\mathrm{O}$. Some of the important bands are shown in Table 1.

\subsection{Electronic spectra and magnetic susceptibility}

The UV-Vis spectra of all the compounds were measured in DMSO at room temperature. The ligands showed two absorption peaks between the range 256-258 and $300-308 \mathrm{~nm}$ and these are assigned to $\pi-\pi^{*}$ and $\mathrm{n}-\pi^{*}$ transition, respectively. The metal complexes showed d$\mathrm{d}$ band in the range of 526-570 $\mathrm{nm}$ and CT bands at lower wavelengths. The $\mathrm{Cu}$ (II) complexes showed a band due to ${ }^{2} \mathrm{~B}_{1 \mathrm{~g}}-{ }^{2} \mathrm{E}_{\mathrm{g}}$ transition ${ }^{41}$ with magnetic moment of 1.82 (1) and 1.76 (4) BM for single unpaired electron. The nickel complexes are diamagnetic with one band corresponding to ${ }^{1} \mathrm{~A}_{1 \mathrm{~g}}-{ }^{1} \mathrm{~B}_{1 \mathrm{~g}}$ transition, ${ }^{42}$ The $\mathrm{Co}(\mathrm{II})$ complexes showed a band at lower region attributable to ${ }^{1} \mathrm{~A}_{1 \mathrm{~g}}-{ }^{1} \mathrm{~B}_{1 \mathrm{~g}}$ transition ${ }^{43}$ with magnetic moment of 2.14 (3) and 2.16 (6) BM. Based on the electronic spectral data and magnetic moment, a square planar geometry is assigned to all the complexes.

\subsection{SEM and EDX}

The surface morphology of ligands and metal complexes was determined by SEM in order to know the change of surface morphology and particle size upon coordination. The micrographs of Schiff base $\mathbf{L}_{1}$ and its metal complexes are shown in Figure 1. Ligand $\mathbf{L}_{1}$ depicts non-uniform platelet structures, particle size is $10 \mu \mathrm{m}$; on the other hand, micrographs of complex 1 indicated the rough surface containing irregular particles with $2 \mu \mathrm{m}$ size. The magnification of image of complex 2 showed cloud-like appearance with particle size of $2 \mu \mathrm{m}$. The complex $\mathbf{3}$ displayed irregular small spherical shape particles of size $2 \mu \mathrm{m}$. The Figure S3 (in SI) depicts the $\mathbf{L}_{2}$ and its metal complexes. Bundle of elongated needles are observed with particle size of $2 \mu \mathrm{m}$ in micrograph of $\mathbf{L}_{2}$, irregular flakes-like particles are observed in micrograph of $\mathbf{4}$, rough fungi-like surface is observed in complex $\mathbf{5}$, and agglomeration of smaller and larger spherical particles faceted on surface of complex $\mathbf{6}$. The observed sizes of complexes 4, 5 and $\mathbf{6}$ are 2, 10 and $10 \mu \mathrm{m}$, respectively. Further, it is observed that upon the change of metal ion in the complex, surface morphology and particle size are also changed. ${ }^{44}$ The chemical composition of Schiff base complexes was determined using energy dispersive X-ray diffraction (EDX). EDX profiles of $\mathbf{L}_{1}$ and its complexes 1, 2 and $\mathbf{3}$ are shown in Figure 1. The peaks for elements like $\mathrm{C}, \mathrm{N}, \mathrm{O}, \mathrm{S}, \mathrm{Cl}$ and respective metal ion $\mathrm{Cu}(\mathrm{II}), \mathrm{Ni}(\mathrm{II})$ and $\mathrm{Co}(\mathrm{II})$ which constitute the ligand molecule $\left(\mathrm{C}_{14} \mathrm{H}_{9} \mathrm{ClN}_{2} \mathrm{OS}\right)$ and complexes such as $\left(\mathrm{C}_{28} \mathrm{H}_{16} \mathrm{Cl}_{2} \mathrm{~N}_{4} \mathrm{O}_{2} \mathrm{~S}_{2} \mathrm{Cu}\right),\left(\mathrm{C}_{28} \mathrm{H}_{16} \mathrm{Cl}_{2} \mathrm{~N}_{4} \mathrm{O}_{2} \mathrm{~S} 2 \mathrm{Ni}\right)$ and $\left(\mathrm{C}_{28} \mathrm{H}_{16} \mathrm{Cl}_{2} \mathrm{~N}_{4} \mathrm{O}_{2} \mathrm{~S}_{2} \mathrm{Co}\right)$ are clearly identified, supporting the proposed structures. ${ }^{45}$

\section{$3.4 X R D$}

The X-ray powder diffraction analysis of the compounds has been performed in order to determine whether the nature of the sample is crystalline or amorphous. The powder diffraction analysis of ligands $\mathbf{L}_{1}$ and $\mathbf{L}_{2}$ shows sharp peaks due to their crystalline nature while the complexes do not exhibit well-defined sharp peaks due to their amorphous nature. The Figure 2 shows powder XRD patterns of $\mathbf{L}_{1}, \mathbf{1}, \mathbf{2}$ and $\mathbf{3}$. The crystallite sizes were calculated by using the following Debye Scherrer's equation:

$$
D=0.9 \lambda / \beta \cos \theta
$$

where, constant 0.9 is the shape factor, $\lambda$ is the $\mathrm{X}$-ray wavelength (1.5406 $\AA$ ), $\theta$ is the Bragg diffraction angle and $\beta$ is the full width at half maximum (FWHM). The experimental average grain sizes of ligands and their metal complexes were found to be $64.32\left(\mathbf{L}_{1}\right), 23.45$ (1), 53.52 (2), $43.21(\mathbf{3}), 44.82\left(\mathbf{L}_{2}\right), 35.42(\mathbf{4}), 23.23$ (5) and $24.32 \mathrm{~nm}(\mathbf{6})$. 


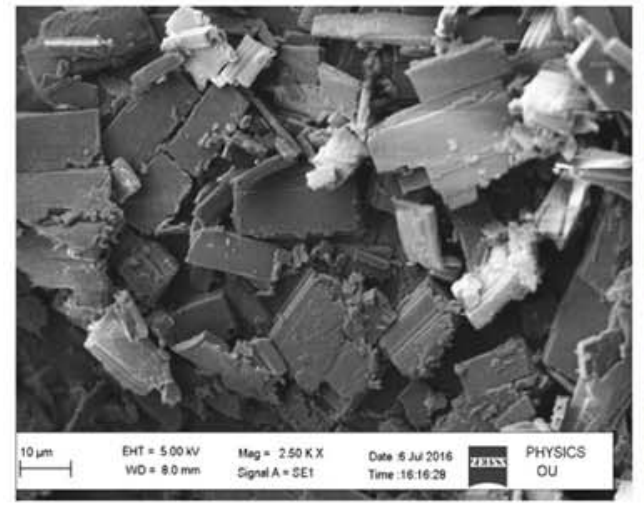

SEM photograph of $\mathrm{L}_{1}$

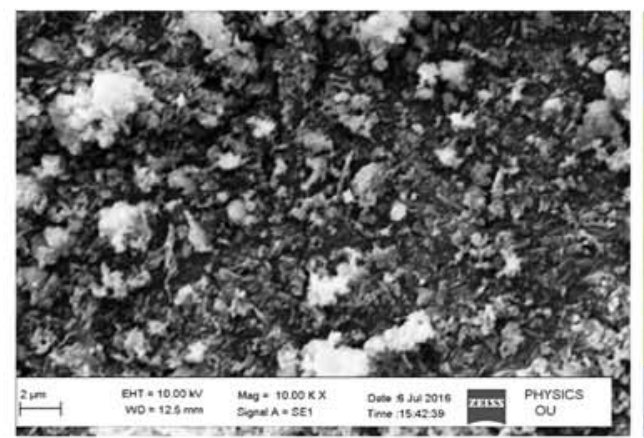

SEM photograph of 1

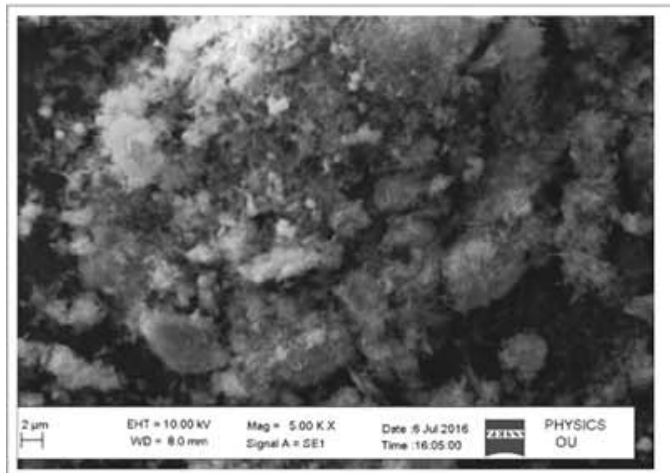

SEM photograph of 2

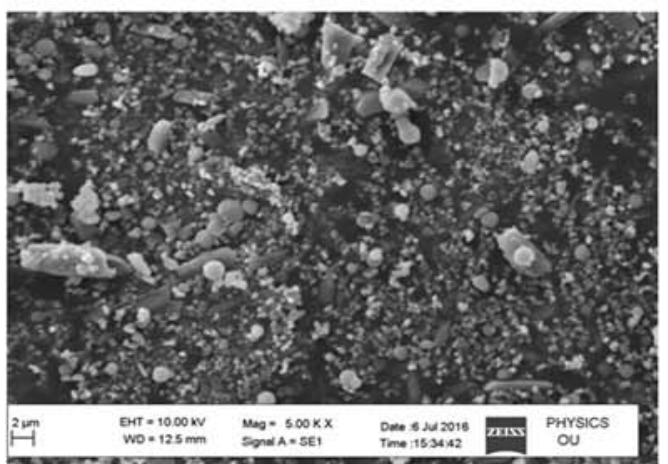

SEM photograph of 3

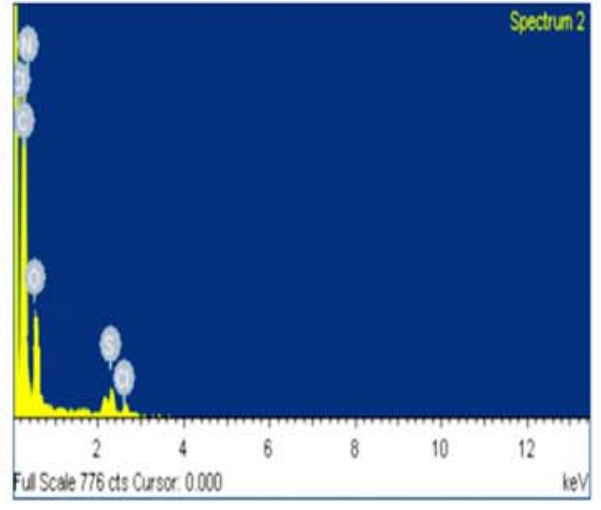

EDX graph of $\mathrm{L}_{1}$

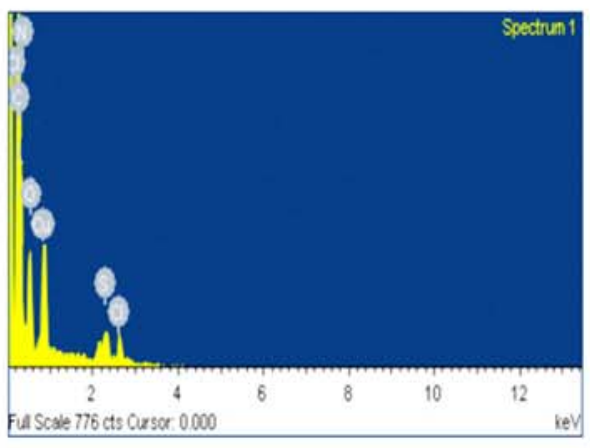

EDX graph of 1

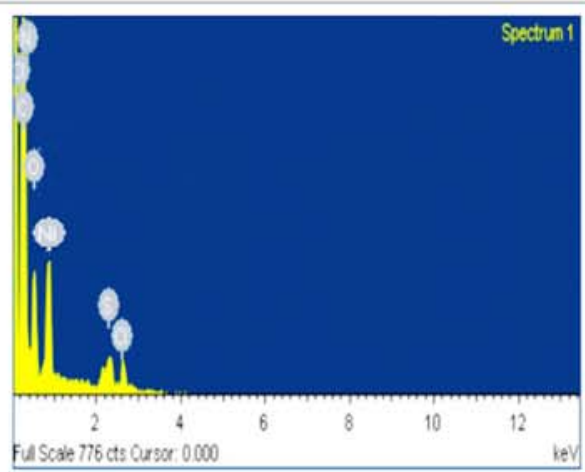

EDX graph of 2

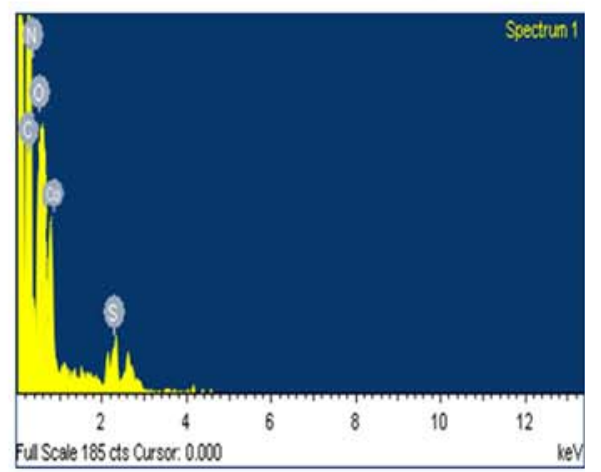

EDX graph of 3

Figure 1. SEM Morphology of $\mathbf{L}_{1}, \mathbf{1}, \mathbf{2}$ and 3. 

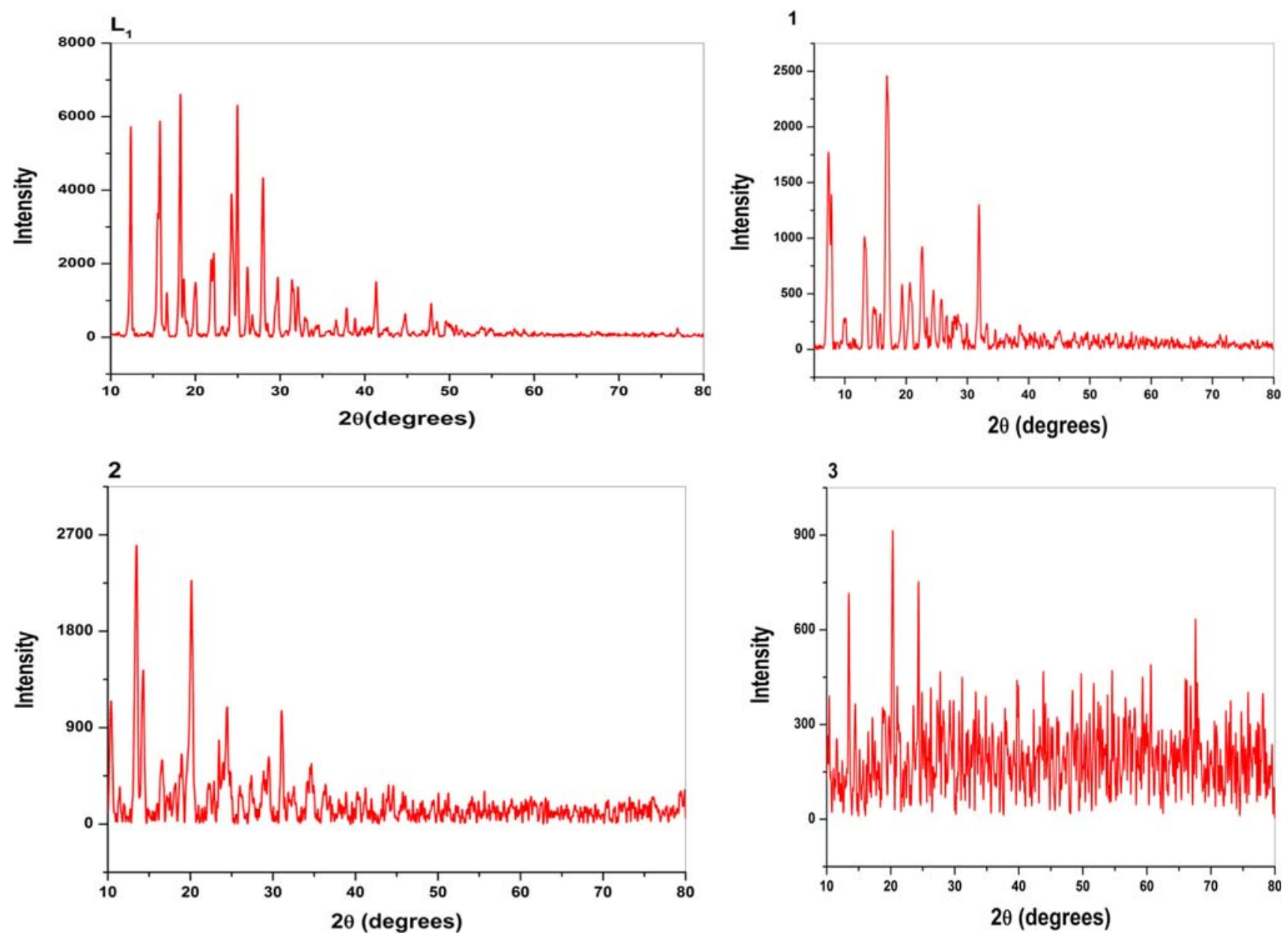

Figure 2. Powder XRD patterns of $\mathbf{L}_{1}, \mathbf{1}, \mathbf{2}$ and $\mathbf{3}$.

\subsection{Mass spectra}

The mass spectra of ligands $\mathbf{L}_{1}$ and $\mathbf{L}_{2}$ showed their molecular ion peaks at $\mathrm{m} / \mathrm{z}=289(\mathrm{M}+1)^{+}$and $\mathrm{m} / \mathrm{z}=300$ $(\mathrm{M}+1)^{+}$, respectively. The copper complexes showed their molecular ion peaks at $\mathrm{m} / \mathrm{z} 659(\mathrm{M}+\mathrm{Na})^{+}$and $698(\mathrm{M}+\mathrm{K})^{+}$which confirmed their stoichiometry as $\mathrm{Cu}\left(\mathrm{L}_{1}\right)_{2}$ and $\mathrm{Cu}\left(\mathrm{L}_{2}\right)_{2}$, respectively. The peaks for the $\mathrm{Ni}(\mathrm{II}), \mathrm{Co}(\mathrm{II})$ complexes were observed at $\mathrm{m} / \mathrm{z} 670$ $\left[\left(\mathrm{L}_{1}\right)_{2} \mathrm{Ni}+\mathrm{K}\right]^{+}, 653\left[\left(\mathrm{~L}_{2}\right)_{2} \mathrm{Ni}\right]+, 655\left[\left(\mathrm{~L}_{1}\right)_{2} \mathrm{Co}+\mathrm{Na}\right]^{+}$, $693\left[\left(\mathrm{~L}_{2}\right)_{2} \mathrm{Co}+\mathrm{K}\right]^{+}$(Shown in Figure S4 in SI). Thus, the mass spectral results along with elemental analysis agreed with the formation of $\left(\mathrm{M}(\mathrm{L})_{2}\right)$ complexes of $1: 2$ stoichiometry.

\subsection{Thermal analysis}

The thermal stability of all the synthesized complexes was determined by the TG-technique. The experiment was carried out under a dynamic nitrogen atmosphere in the temperature range $30-1000^{\circ} \mathrm{C}$ at heating rate of $10^{\circ} \mathrm{C} \mathrm{min}{ }^{-1}$. The thermal behaviour of the complexes were found to be similar for the six complexes. Twosteps were involved in the weight loss process. The first step corresponds to the collapse of the starting material. The second step involves the removal of total ligand moiety and above this temperature metal oxide (MO) was left as residue. Representative thermograms of 1-3 complexes are shown in Figure 3. In complexes 1, 2 and 3, the first step degradation in the range of $250-390^{\circ} \mathrm{C}$ corresponds to removal of partial ligand moiety. Second step corresponds to departure of total ligand moiety in the range of $332-753^{\circ} \mathrm{C}$, and above this temperature, horizontal curve was obtained suggesting formation of metal oxide.

\subsection{ESR spectra}

The electron spin resonance spectra of $\mathrm{Cu}$ (II) complexes were recorded in DMSO at liquid nitrogen temperature (LNT). The ESR studies give information about the sharing of the single unpaired electron of $\mathrm{Cu}$ (II) complexes with ligand and hence the nature of the bonding between the metal ion and its ligands can be 


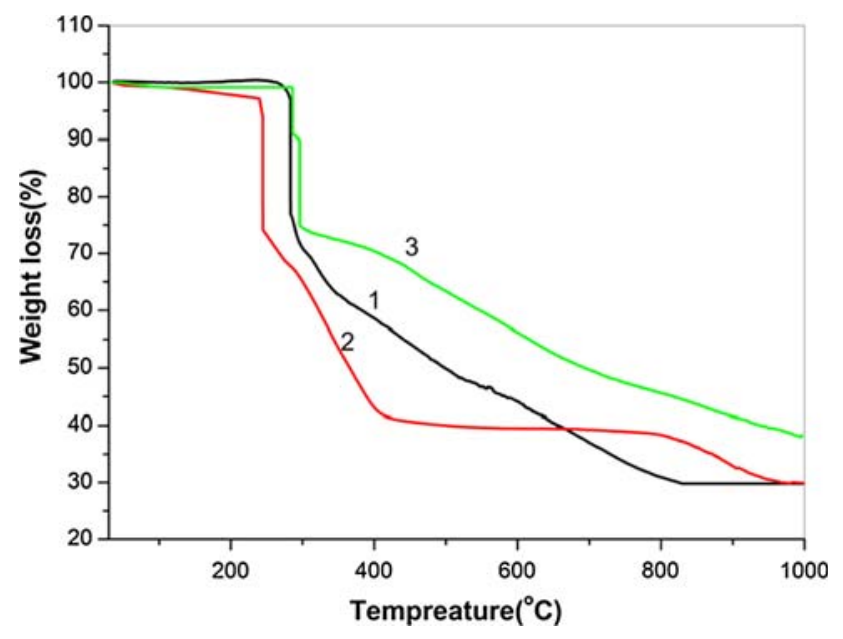

Figure 3. Thermograms of complexes 1, 2 and $\mathbf{3}$.

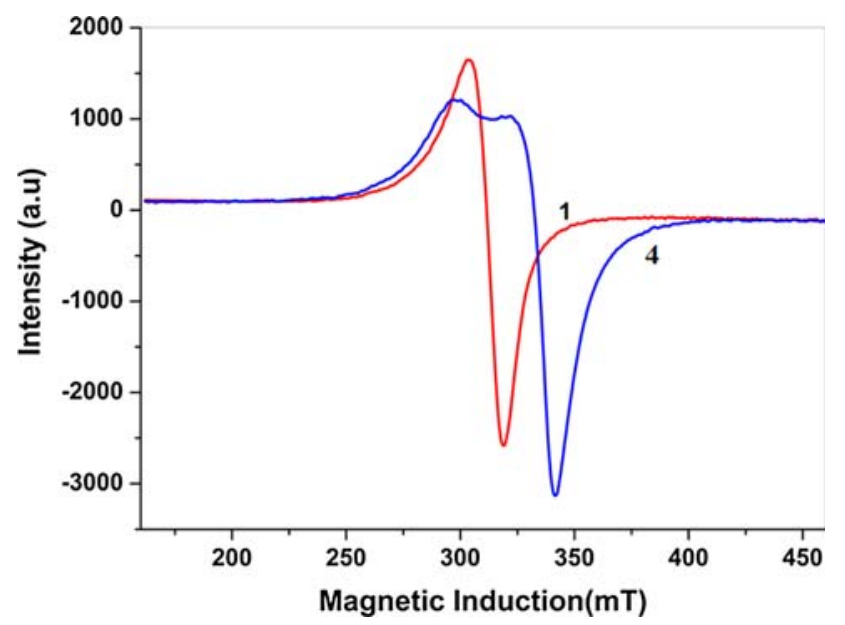

Figure 4. Electron spin resonance spectra of complexes 1 and 4.

known. Figure 4 depicts the ESR spectra of 1 and 4 . The trend $\mathrm{g}_{\|}>\mathrm{g}_{\perp}>\mathrm{g}_{\mathrm{e}}(2.0023)$ observed in these complexes indicate that the unpaired electron residing in the $d_{x^{2}-y^{2}}$ orbital, and this evidence is in favour for $\mathrm{Cu}$ (II) ion having square planar geometry. The $\mathrm{g}_{\|}$value of these complexes lies below $2.3\left(\mathrm{~g}_{\|}<2.3\right)$ which indicate covalent environment around the $\mathrm{Cu}(\mathrm{II})$ ion. ${ }^{46}$ In $\mathrm{Cu}$ (II) complexes, the calculated $\mathrm{G}\left[\mathrm{G}=\left(\mathrm{g}_{\|}-2.0023\right)\right.$ $\left./\left(\mathrm{g}_{\perp}-2.0023\right)\right]$ value is 1.539 for complex 1 and 1.618 for 4 . The $\mathrm{G}$ values of $\mathrm{Cu}$ (II) complexes less than 4 give a hint of considerable exchange interaction in the complexes. ${ }^{47}$

\subsection{DNA binding studies}

\section{8a Electronic absorption spectroscopic studies:}

Electronic absorption study is one of the most reliable technique to examine the binding affinity and binding mode of metal complexes with CT-DNA. ${ }^{48,49}$ In this study, absorption titration concentration of CT-DNA is varied while the concentration of metal complex is kept constant. In general, the absorption spectrum of a complex shows a red shift and hypochromism, indicating intercalation mode of binding between complexes and DNA. The binding tendency was determined by monitoring the change of the absorbance of the complex when the concentration of CT-DNA was increased. Absorption spectra of 1, 3, 4 and 6 are shown in Figure 5. Upon increasing concentration of CT-DNA to the metal complex, absorbance decreased (hypochromism) and wavelength shifted towards long wavelength (red shift) due to a strong stacking interaction between the aromatic chromophore of the complex and the adjacent base pairs of DNA. ${ }^{50}$ The extent of the hypochromism commonly parallels with the intercalative binding strength. ${ }^{51}$ The electronic absorption spectra of $\mathbf{1}(400 \mathrm{~nm}), \mathbf{2}(401 \mathrm{~nm})$, $\mathbf{3}(403 \mathrm{~nm}), \mathbf{4}(377 \mathrm{~nm}), \mathbf{5}(391 \mathrm{~nm})$ and $\mathbf{6}(390 \mathrm{~nm})$ show intense absorption bands. In order to compare the DNA binding propensity of the compounds quantitatively, the intrinsic binding constant $\mathrm{K}_{\mathrm{b}}$ of the complexes with CTDNA was determined according to the eq. 2.

$$
[\mathrm{DNA}] /\left(\varepsilon_{\mathrm{a}}-\varepsilon_{\mathrm{f}}\right)=[\mathrm{DNA}] /\left(\varepsilon_{\mathrm{b}}-\varepsilon_{\mathrm{f}}\right)+1 / \mathrm{K}_{\mathrm{b}}\left(\varepsilon_{\mathrm{b}}-\varepsilon_{\mathrm{f}}\right)
$$

Here, $\mathrm{K}_{\mathrm{b}}$ is the binding constant, [DNA] is the concentration of DNA in the base pairs, $\varepsilon_{\mathrm{a}}$ is apparent coefficient equal to $\mathrm{A}_{\mathrm{obsd}} /[\mathrm{complex}], \varepsilon_{\mathrm{f}}$ and $\varepsilon_{\mathrm{b}}$ correspond to the extinction coefficients of the free and fully bound forms of the complex, respectively. Using this formula, the binding constants $\mathrm{K}_{\mathrm{b}}$ were calculated and found to be, $1.57 \pm 0.16 \times 10^{5} \mathrm{M}^{-1}$ for complex (1), $1.36 \pm 0.15 \times 10^{5} \mathrm{M}^{-1}(\mathbf{4}), 3.14 \pm 0.13 \times 10^{4} \mathrm{M}^{-1}(\mathbf{2})$, $1.14 \pm 0.16 \times 10^{4} \mathrm{M}^{-1}(\mathbf{5}), 2.32 \pm 0.2 \times 10^{4} \mathrm{M}^{-1}$ (3) and $2.1 \pm 0.18 \times 10^{4} \mathrm{M}^{-1}(\mathbf{6})$. This absorption spectral result reveals that the $\mathrm{Cu}$ (II) complexes have greater binding affinity than the $\mathrm{Ni}$ (II) and $\mathrm{Co}(\mathrm{II})$ complexes.

3.8b Fluorescence studies: The EB fluorescence displacement experiments were carried out to explore further the interaction mode between CT-DNA and the complexes. EB in buffer solution has low fluorescence intensity due to fluorescence quenching of the free EB by the solvent molecule, and its emission intensity dramatically increases when (incubate $15 \mathrm{~min}$ ) it intercalatively binds with DNA (Figure S5 in Supplementary Information). The intensity saturates for $[\mathrm{EB}] \sim 12.5 \mu \mathrm{M}$ for $[\mathrm{DNA}]=125 \mu \mathrm{M}$. This high intensity is reduced by successive addition of DNA binding agents (complexes) to EB-DNA system. ${ }^{31,52,53}$ In the present work, on increasing the concentration of the $\mathrm{Cu}$ (II), $\mathrm{Ni}$ (II) and $\mathrm{Co}$ (II) complexes, the fluorescence emission intensity of the DNA-EB complex decreased slowly (Figure 6). The flu- 

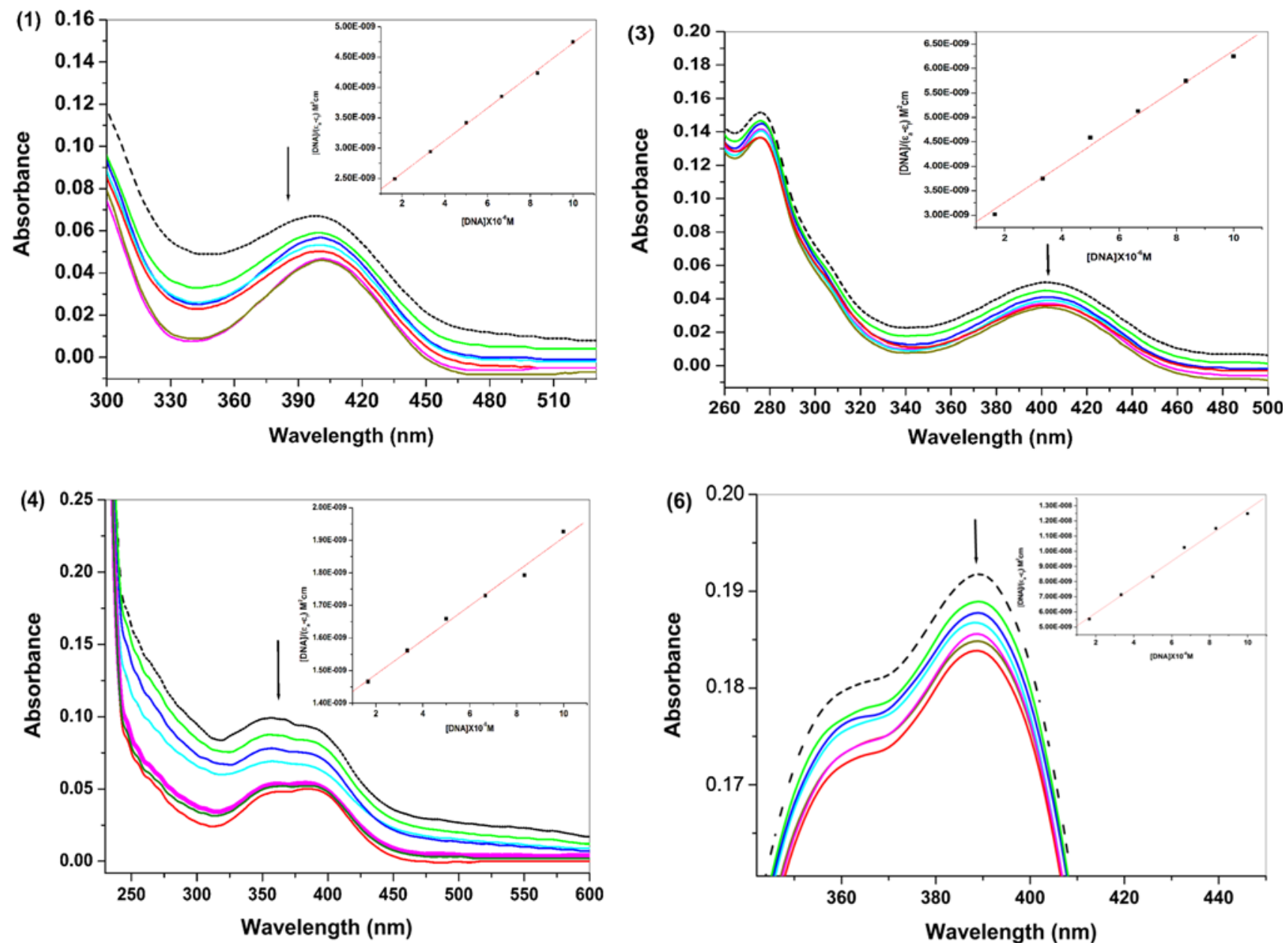

Figure 5. Absorption spectra of complexes 1, 3, 4 and $\mathbf{6}$ (In Tris- $\mathrm{HCl} / \mathrm{NaCl}$ buffer) on addition of increasing concentration of CT-DNA. Conditions: [complex] $=10 \mu \mathrm{M},[\mathrm{DNA}]=0-10 \mu \mathrm{M}$. Arrow shows changes in absorbance upon increasing amounts of CT DNA. Inset: Plot of [DNA] $/\left(\varepsilon_{\mathrm{a}}-\varepsilon_{\mathrm{f}}\right)$ versus [DNA] for the titration of DNA with metal complexes.

orescence emission intensities at $592 \mathrm{~nm}$ (excitation at $350 \mathrm{~nm}$ ) diminished with the increase of complex concentration, which suggested that the complexes could displace DNA-bound EB and bind to CT-DNA at the intercalation site with almost the same affinity. ${ }^{54}$ The $\mathrm{K}_{\mathrm{sv}}$ is calculated from the slope of the plot $\mathrm{I}_{0} / \mathrm{I}$ versus r. The apparent binding constant was calculated to be $1.57 \pm 0.16 \times 10^{5} \mathrm{M}^{-1}(\mathbf{1}), 1.36 \pm 0.15 \times 10^{5} \mathrm{M}^{-1}(\mathbf{4})$, $7.4 \pm 0.13 \times 10^{4} \mathrm{M}^{-1}(\mathbf{2}), 6.1 \pm 0.17 \times 10^{4} \mathrm{M}^{-1}(\mathbf{5})$, $1.9 \pm 0.13 \times 10^{4} \mathrm{M}^{-1}(\mathbf{3})$, and $1.3 \pm 0.19 \times 10^{4} \mathrm{M}^{-1}(\mathbf{6})$. These results indicate $\mathrm{Cu}(\mathrm{II})$ complex binds to the DNA by intercalative mode more efficiently than $\mathrm{Ni}$ (II) and $\mathrm{Co}$ (II) complexes, which is consistent with electronic absorption spectral results described in Section 3.8a.

3.8c Viscosity studies: The universally acceptable tool to find the binding mode of complexes to CT-DNA further is viscometric measurement and it is one of the most definite methods in illustrating the binding mode of complexes to DNA in solution in the absence of crys- tallographic structural data. In classical intercalation, length of DNA helix increases due to complexes binding between the base pairs of the DNA leading to increase in viscosity of the DNA solution. In dissimilarity, a partial intercalation mode can kink or bend the DNA helix, resulting in a decrease in the effective length and also viscosity. ${ }^{55}$ Whereas, non-intercalation binding, such as electrostatic or groove binding, has a smaller effect on viscosity. The effect of all the metal complexes on the viscosity of DNA solution at $30 \pm 1{ }^{\circ} \mathrm{C}$ is shown in Figure 7 and Figure S5 (in SI). The results on viscosity clearly showed that all the complexes can bind intercalatively. The increase is in the following order: $\mathbf{1}>\mathbf{4}$ $>\mathbf{2}>\mathbf{5}>\mathbf{3}>\mathbf{6}$. The affinity complexes to DNA are comparable with groove binding (GB) agents like copper(II) or nickel(II) mesalamine complexes ${ }^{56}$ (shown in Figure 7 and Figure S6). These results confirmed that binding is intercalative. The obtained results of viscometric measurements are consistent with the results of the absorption and emission studies. 

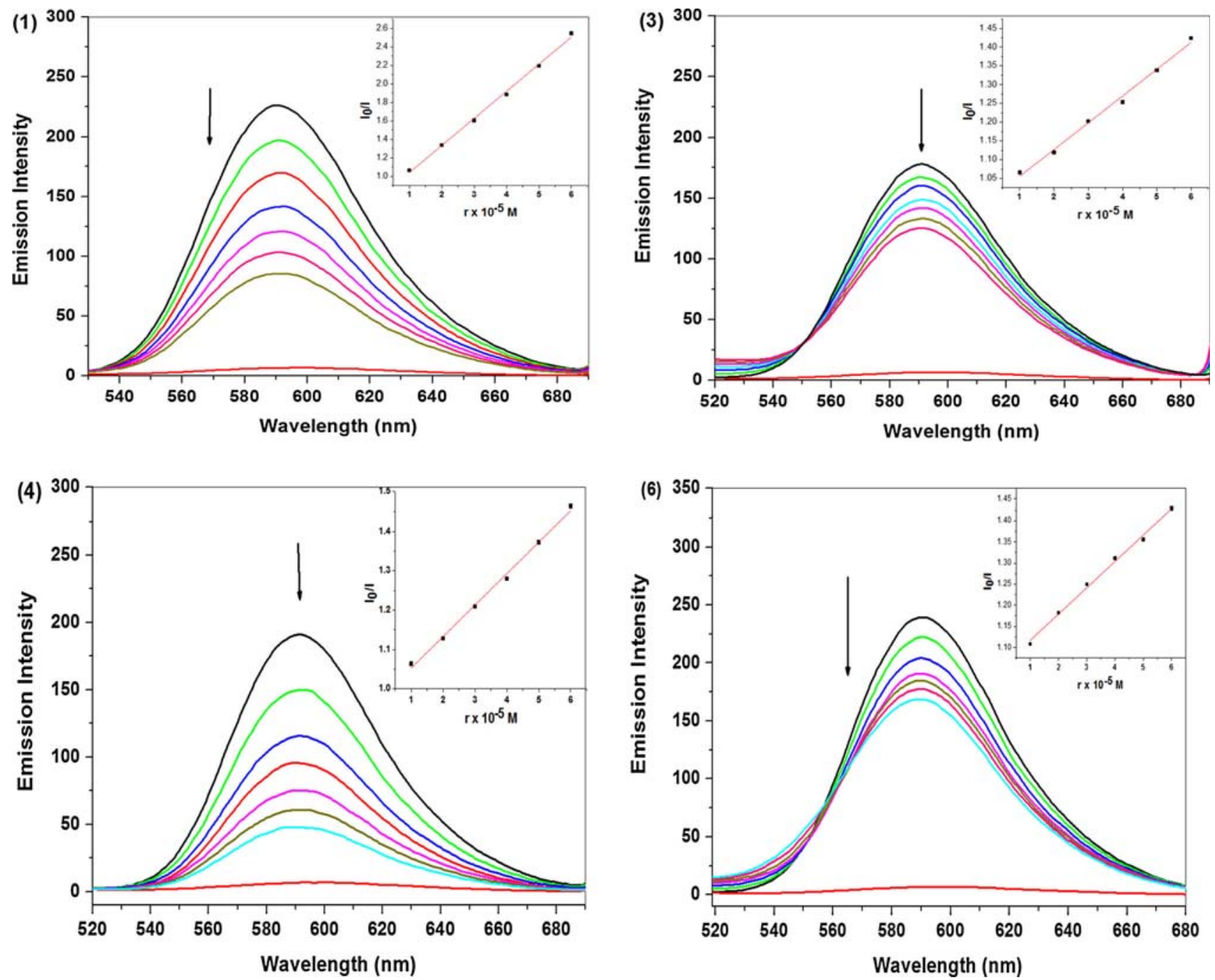

Figure 6. Quenched Fluorescence spectra of DNA $(125 \mu \mathrm{M})$ bound to EB $(12.5 \mu \mathrm{M})$ system with the addition of 1, 3, 4 and 6. Arrow shows the decreasing emission intensity upon increasing concentration of the the complexes $(0-60 \mu \mathrm{M})$. Inset: $\mathrm{I}_{0} / \mathrm{I}$ versus $\mathrm{r}$.

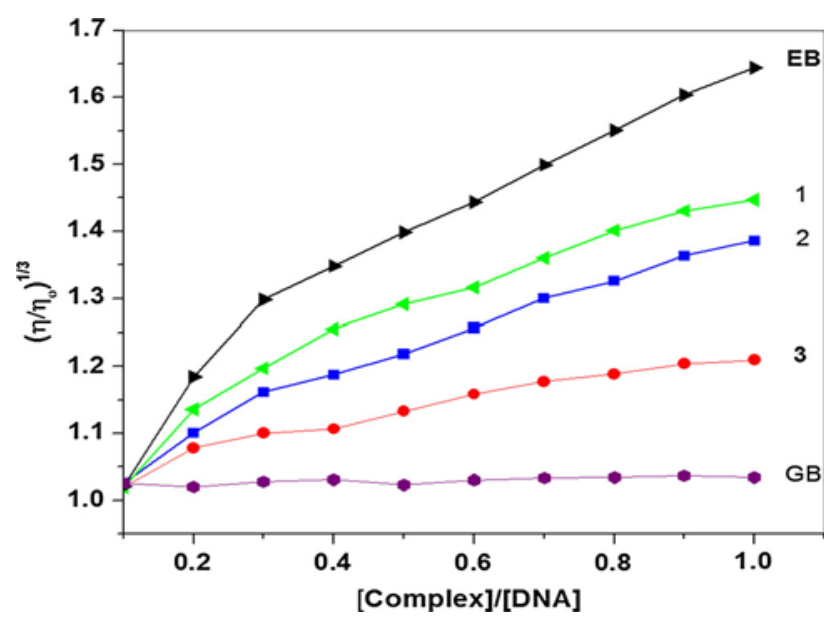

Figure 7. Viscosity of the solutions of EB, complexes 1, 2, 3 and Nickel (II) mesalamine complex (GB).

\subsection{DNA cleavage}

The chemical nuclease efficacy of complexes 1-6 has been studied by gel electrophoresis by using supercoiled pBR322 DNA as the substrate in the medium of $5 \mathrm{mM}$ Tris- $\mathrm{HCl} / 50 \mathrm{mM} \mathrm{NaCl}$ buffer $(\mathrm{pH}=7.4)$ in the presence of hydrogen peroxide and UV-light. When circular plasmid DNA is conducted by electrophoresis, the fastest migration will be observed for the super coiled (SC) form-I. If one strand is cleaved, the SC form will relax to produce a slow-moving open circular (OC) form-II or nicked form. If both strands are cleaved, a linear formIII will be generated that migrates at a rate in between the form-I and form-II. ${ }^{57,58}$

Figure 8 exhibits the cleavage patterns of synthesized $\mathrm{Cu}(\mathrm{II}), \mathrm{Ni}$ (II) and $\mathrm{Co}(\mathrm{II})$ metal complexes. In the pho- 


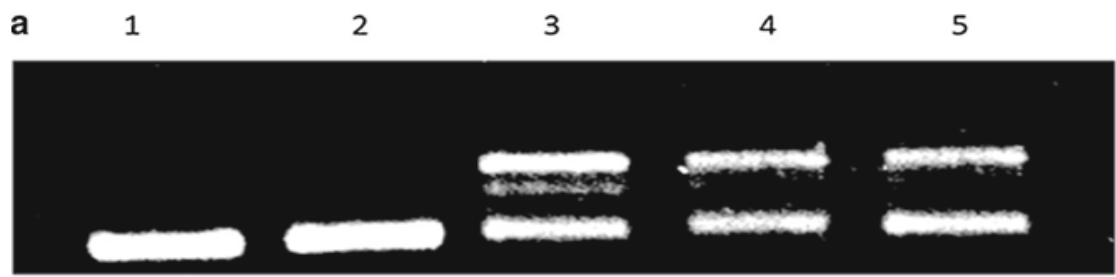

form II

form III

form I

b

1

2

3

4

5

6

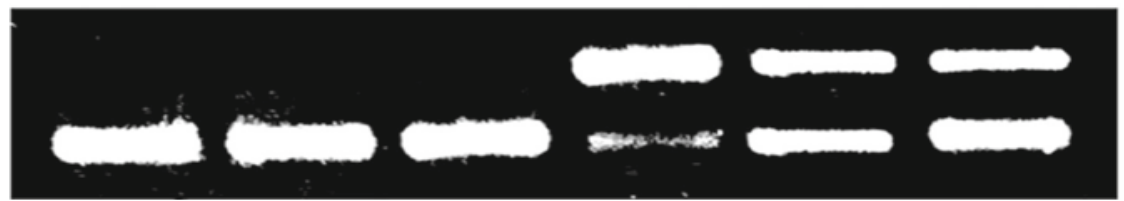

form II

form I

Figure 8. a Photoactivated cleavage of supercoiled pBR322 DNA $(0.2 \mu \mathrm{g}, 33.3 \mu \mathrm{M})$ by the complexes at $37^{\circ} \mathrm{C}$ in $5 \mathrm{mM}$ Tris $\mathrm{HCl} / 50 \mathrm{mM} \mathrm{NaCl}$ buffer by UV irradiation at $345 \mathrm{~nm}$. Lane 1, DNA control; Lane 2, DNA + $\mathbf{L}_{1}(20 \mu \mathrm{M})$; Lane 3, DNA + $1(20 \mu \mathrm{M})$; Lane 4, DNA + $2(20 \mu \mathrm{M})$; Lane 5, DNA + $3(20 \mu \mathrm{M})$. b Oxidative cleavage of supercoiled pBR322 DNA $(0.2 \mu \mathrm{g} / \mu \mathrm{L}, 33.3 \mu \mathrm{M})$ at $37^{\circ} \mathrm{C}$ in $5 \mathrm{mM}$ Tris $\mathrm{HCl} / 50 \mathrm{mM} \mathrm{NaCl}$ buffer. Lane 1, DNA control; Lane 2, DNA $+\mathrm{H}_{2} \mathrm{O}_{2}(1 \mathrm{mM})$; Lane 3, DNA $+\mathrm{H}_{2} \mathrm{O}_{2}(1 \mathrm{mM})+\mathrm{L}_{1}$; Lane 4, DNA $+\mathrm{H}_{2} \mathrm{O}_{2}$ $(1 \mathrm{mM})+1(20 \mu \mathrm{M}) ;$ Lane 5, DNA $+\mathrm{H}_{2} \mathrm{O}_{2}(1 \mathrm{mM})+2(20 \mu \mathrm{M})$; Lane 6, DNA $+\mathrm{H}_{2} \mathrm{O}_{2}(1$ $\mathrm{mM})+\mathbf{3}(20 \mu \mathrm{M})$.

Table 2. Minimum inhibition zone ( $\mathrm{mm})$ of complexes $(1 \mathrm{mg} / \mathrm{mL})$

\begin{tabular}{lllll}
\hline \multirow{2}{*}{ Compound } & \multicolumn{4}{l}{ Bacterial inhibition zone $(\mathrm{mm})$} \\
\cline { 2 - 5 } & \multicolumn{2}{l}{ Gram-negative bacteria } & Gram-positive bacteria \\
\cline { 2 - 5 } & E. coli & P. putida & K. pneumoniae & B. subtilis \\
\hline BTEMCP $\left(\mathbf{L}_{1}\right)$ & 11 & 8 & 9 & 10 \\
{$\left[\mathrm{Cu}(\mathrm{BTEMCP})_{2}\right](\mathbf{1})$} & 26 & 23 & 21 & 24 \\
{$\left[\mathrm{Ni}(\mathrm{BTEMCP})_{2}\right](\mathbf{2})$} & 18 & 15 & 16 & 17 \\
{$\left[\mathrm{Co}(\mathrm{BTEMCP})_{2}\right](\mathbf{3})$} & 20 & 16 & 17 & 19 \\
$\mathrm{BTEMNP}\left(\mathbf{L}_{2}\right)$ & 9 & 7 & 10 & 8 \\
{$\left[\mathrm{Cu}(\mathrm{BTEMNP})_{2}\right](\mathbf{4})$} & 22 & 19 & 17 & 21 \\
{$\left[\mathrm{Ni}(\mathrm{BTEMNP})_{2}\right](\mathbf{5})$} & 15 & 12 & 13 & 15 \\
{$\left[\mathrm{Co}(\mathrm{BTEMNP})_{2}\right](\mathbf{6})$} & 19 & 17 & 14 & 17 \\
{$\left[\mathrm{Cu}(\mathrm{Aco})_{2} \mathrm{H}_{2} \mathrm{O}\right]$} & 2 & - & - & 3 \\
{$\left[\mathrm{Ni}(\mathrm{Acco})_{2} 4 \mathrm{H}_{2} \mathrm{O}\right]$} & 2 & - & - & 1 \\
{$\left[\mathrm{Co}(\mathrm{Aco})_{2} 4 \mathrm{H}_{2} \mathrm{O}\right]$} & 1 & - & - & 2 \\
$\mathrm{Ampicillin}$ & 30 & 29 & 25 & 28 \\
\hline
\end{tabular}

tolytic method, control (lane 1) and $\mathbf{L}_{1}$ (lane 2) do not show any cleavage of plasmid DNA whereas complexes 1 (lane 3), 2 (lane 4) and 3 (lane 5) effectively cleaved the plasmid DNA into nicked form, and, especially, complex 1 cleaved DNA into linear form. In the oxidative method, control (lane 1), DNA $+\mathrm{H}_{2} \mathrm{O}_{2}$ (lane 2) and $\mathbf{L}_{1}$ (lane 3) do not show any significant cleavage of plasmid DNA whereas complexes 1 (lane 4), 2 (lane 5) and 3 (lane 6) cleaved DNA into nicked form. These results showed that complex $\mathbf{1}(\mathrm{Cu})$ has a good cleavage activity than complexes $\mathbf{2}(\mathrm{Ni})$ and $\mathbf{3}(\mathrm{Co})$. Further, it is observed that the complexes 1, 2 and $\mathbf{3}$ showed better cleavage activity than complexes 4, 5 and $\mathbf{6}$ (Figure S7 in SI)

\subsection{Antibacterial activity}

The in vitro biological effects of the two ligands and six complexes were tested against various gram positive, gram negative bacteria, namely, Bacillus subtilis, Escherichia coli, Pseudomonas putida, and Klebsiella pneumonia and the results are presented in Table 2 and Figure 9. All the metal complexes ( $1 \mathrm{mg} / \mathrm{mL}$ in DMSO) showed better activity compared to free ligands. The results are compared with Ampicillin. Increased activity of the complexes is attributed to increase in the lipophilic nature of the complexes arising from chelation, which reduces the polarity of the metal ion mainly because 


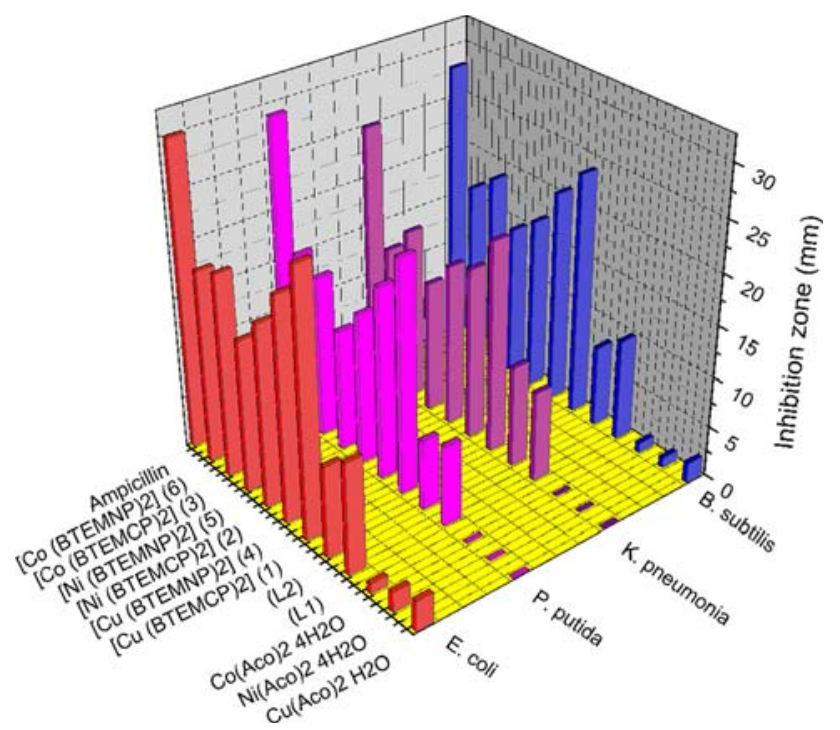

Figure 9. Antibacterial activity of synthesized compounds with E. coli, P. putida, K. pneumonia (Gram Negative) and B. subtilis (Gram Positive) and Ampicillin as a standard.

of possible $\pi$ electron delocalization within the intact chelate ring and partial sharing of its positive charge with the donor groups. The lipophilic nature of the metal ion is also increased by chelation which subsequently favors the permeation through the lipid layer of the cell membrane. The mode of action of the complexes involves the formation of hydrogen bonds with the imino group by the active sites leading to interference with the cell wall synthesis. This hydrogen bond formation damages the cytoplasmic membrane, and the cell permeability may also be distorted leading to cell fatality. ${ }^{59}$ Further, it is observed that the $\mathrm{Cu}$ (II) complexes showed larger inhibition zone than $\mathrm{Ni}(\mathrm{II})$ and $\mathrm{Co}(\mathrm{II})$ complexes.

\section{Conclusions}

In the present investigation, we have synthesized mononuclear $\mathrm{Cu}(\mathrm{II}), \mathrm{Ni}(\mathrm{II})$ and $\mathrm{Co}(\mathrm{II})$ complexes using novel Schiff base ligands $\mathrm{L}_{1}$ and $\mathrm{L}_{2}$. The Schiff bases and metal complexes have been characterized by spectral and analytical techniques. Spectral and magnetic susceptibility measurements revealed that all the complexes exhibit square planar geometry. The binding of the complexes with CT-DNA were studied by UVVis absorption, fluorescence spectroscopy and viscosity measurements. It was found that binding with CT-DNA is by intercalative mode. The cleaving tendency of the complexes was tested with pBR322 DNA in the presence of $\mathrm{H}_{2} \mathrm{O}_{2}$ and UV light, which revealed that the complexes effectively cleave the DNA. Among all the complexes, $\mathrm{Cu}$ (II) complex (1) showed better cleavage activity. Further, antibacterial activity of the synthesized compounds were studied and the metal complexes have shown promising more activity than the corresponding Schiff bases.

\section{Supplementary Information (SI)}

Spectral $\left({ }^{1} \mathrm{H}-\mathrm{NMR}\right.$, IR, SEM and Mass), Fluorescence spectra of EB bound to CT DNA (Figure S5), viscosity (Figure S6 for 4, 5 and $\mathbf{6}$ ) and DNA cleavage (Figure S7 for complexes $\mathbf{4 , 5}$ and $\mathbf{6}$ ) are given as Supplementary information, which is available at www.ias.ac.in/chemsci.

\section{Acknowledgements}

We express our sincere and heartfelt thanks to the Head, Department of Chemistry for providing the necessary facilities. We are thankful to the Director, CFRD, Osmania University, Hyderabad, and the Director, IICT, Hyderabad, and the SAIF, IIT Bombay for providing spectral and analytical data. We are also thankful to CSIR, New Delhi, DST-SERB, DST-PURSE, DST-FIST and UGC-UPE (FAR) for providing financial assistance. Funding was provided by Council for Scientific and Industrial Research (Grant No. 09/132(0799)/2012-EMR-I).

\section{References}

1. Rosenberg B, Van Camp L and Krigas T 1965 Inhibiton of cell division in Escherichia coli by electrolysis products from a platinum electrode Nature 205698

2. Barton J K and Lolis E 1985 Chiral discrimination in the covalent binding of bis(phenanthroline)dichlororuthenium(II) to B-DNA $J$. Am. Chem. Soc. 107708

3. Guo Z and Sadler P J 2000 Medicinal inorganic chemistry Adv. Inorg. Chem. 49183

4. Erkkila K E, Odom D T and Barton J K 1999 Recognition and reaction of metallointercalators with DNA Chem. Rev. 992777

5. Lippert B 2000 Multiplicity of metal ion binding patterns to nucleo bases Coord. Chem. Rev. 200487

6. Li C, Liu S L, Guo L H and Chen D P 2005 A new chemically amplified electrochemical system for DNA detection in solution Electrochem. Commun. Chem. 723

7. Howe-Grant M and Lippard S J 1979 Binding of Platinum (II) Intercalation reagents to deoxyribonucleic acid. Dependence on base-pair composition, nature of the intercalator, and ionic strength Biochemistry 185757

8. Blaskoa A and Bruice T C 1999 Recent studies of nucleophilic, general-acid, and metal ion catalysis of phosphate diester hydrolysis Acc. Chem. Res. 32475

9. Burrows C J and Muller J G 1998 Oxidative Nucleobase Modifications Leading to Strand Scission Chem. Rev. 98 1109

10. Sinha R P and Hader D P 2002 UV-induced DNA damage and repair: a review Photochem. Photobiol. Sci. 1225 
11. Klein A V and Hambley T W 2009 Platinum drug distribution in cancer cells and tumors Chem. Rev. 1094911

12. Gust R, Beck W, Jaouen G and Schonenberger H 2009 Optimization of cisplatin for the treatment of hormone dependent tumoral diseases Part 1: use of steroidal ligands Coord. Chem. Rev. 2532742

13. Soni B, Ranawat M S, Sharma R, Bhandari A and Sharma S 2010 Synthesis and evaluation of some new benzothiazole derivatives as potential antimicrobial agents Eur. J. Med. Chem. 452938

14. Shafi S, Alam M M, Naveen M, Chaitanya M, and Vanaja G 2012 Synthesis and in vitro anti-HIV activity of $N$-1,3-benzo[d]thiazol-2-yl-2-(2-oxo-2H-chromen4-yl)acetamide derivatives using MTT method Eur. J. Med. Chem. 49324

15. Bhavsar D, Trivedi J, Parekh S, Savant M, Thakrar S, Bavishi A, Radadiya A, Vala H, Lunagariya J, Parmar M, Paresh L, Loddo R and Shah A 2011 Synthesis and in vitro anti-HIV activity of $N$-1,3-benzo[ $d]$ thiazol-2-yl2-(2-oxo-2 H-chromen-4-yl)acetamide derivatives using MTT method Bioorg. Med. Chem. Lett. 213443

16. Delmas F, Avellaneda A and Giorgio C D et.al 2004 Synthesis and antileishmanial activity of (1,3-benzothiazol2-yl) amino-9-(10H)-acridinone derivatives Eur. J. Med. Chem. 39685

17. Pereira G A, Massabni A C and Castellano E E 2012 A broad study of two new promising antimycobacterial drugs: $\operatorname{Ag}(\mathrm{I})$ and $\mathrm{Au}(\mathrm{I})$ complexes with 2-(2thienyl)benzothiazole Polyhedron 38296

18. Burger A and Sawhey S N 1968 Antimalarials III Benzothiazole amino alcohols J. Med. Chem. 11270

19. Sharpe T R, Cherkofsky S C, Hewes W E, Smith D H, Gregory W A, Haber S B, Leadbetter M R and Whitney J G 1985 Preparation and antiarthritic and analgesic activity of 4,5-diaryl-2-(substituted thio)-1H-imidazoles and their sulfoxides and sulfones J. Med. Chem. 28118

20. Fu X B, Lin Z H, Liu H F and Le X Y 2014 A new ternary copper(II) complex derived from 2(2/-pyridyl)benzimidazole and glycylglycine: Synthesis, characterization, DNA binding and cleavage, antioxidation and HSA interaction Spectrochim. Acta A Mol. Biomol. Spectrosc. 12222

21. Porchia M, Dolmella A, Gandin V, Marzano C, Peruzzo M P V, Refosco F, Santini C and Tisato F 2013 Neutral and charged phosphine/scorpionate copper(I) complexes: Effects of ligand assembly on their antiproliferative activity Eur. J. Med. Chem. 59218

22. Mancin F, Scrimin P, Tecilla P and Tonellato U 2005 Artificial metallonucleases Chem. Commun. 2005 25402548. doi:10.1039/b418164f

23. Manikandamathavan V M, Parameswari R P, Weyhermuller T, Vasanthi H R and Nair B U 2011 Cytotoxic copper (II) mixed ligand complexes: Crystal structure and DNA cleavage activity Eur. J. Med. Chem. 464537

24. Borges B E, Teixeira V R, Appel M H, Steclan C A, Rigo F and Neto F F et al. 2013 De novo galectin-3 expression influences the response of melanoma cells to isatin-Schiff base copper(II) complex-induced oxidative stimulus Chem. Biol. Interact. 20637

25. Selvakumaran N, Bhuvanesh N S P, Endo A and Karvembu R 2014 Synthesis, structure, DNA and protein binding studies, and cytotoxic activity of
nickel(II) complexes containing 3,3-dialkyl/aryl-1-(2,4dichlorobenzoyl)thiourea ligands Polyhedron 7595

26. Shafaatian B, Soleymanpour A, Oskouei N K, Notash B and Rezvani S A 2014 Synthesis, crystal structure, fluorescence and electrochemical studies of a new tridentate Schiff base ligand and its nickel(II) and palladium(II) complexes Spectrochim. Acta. Part A 128363

27. Bottcher A, Takeuchi T, Simon M I, Meade T J and Gray H B 1995 Irreversible enzymatic inhibition by cobalt Chelate complexes J. Inorg. Biochem. 59221

28. Das S, Ranjani A and Gayathri L et al. 2016 Recognition of self-assembled water-nitrate cluster in a $\mathrm{Co}$ (III)2,2'-bipyridine host: synthesis, x-ray structure, DNA cleavage, molecular docking and anticancer activity $J$. Chem. Sci. 1281755

29. Widom J and Baldwin R L 1980 Cation-induced toroidal condensation of DNA studies with $\mathrm{Co}^{3+}\left(\mathrm{NH}_{3}\right)_{6} J . M o$. Biol. 144431

30. Kumar M P, Tejaswi S, Rambabu A, Veerendra Kumar A $\mathrm{K}$ and Shivaraj 2015 Synthesis, crystal structure, DNA binding and cleavage studies of copper(II) complexes with isoxazole Schiff base Polyhedron 102111

31. Rambabu A, Kumar M P, Tejaswi S, Vamsikrishna N and Shivaraj 2016 DNA interaction, antimicrobial studies of newly synthesized copper (II) complexes with 2-amino6-(trifluoromethoxy)benzothiazole Schiff base ligands $J$. Photochem. Photobiol. B 165147

32. Vamsikrishna N, Kumar M P, Tejaswi S, Rambabu A and Shivaraj 2016 DNA binding, cleavage and antibacterial activity of mononuclear $\mathrm{Cu}(\mathrm{II}), \mathrm{Ni}(\mathrm{II})$ and $\mathrm{Co}(\mathrm{II})$ complexes derived from novel benzothiazole schiff bases $J$. Fluoresc. 261317

33. Marmur J 1961 A procedure for the isolation of deoxyribonucleic acid from micro-organisms J. Mol. Biol. 3208

34. Reichmann M E, Rice S A, Thomas C A and Doty $\mathrm{P}$ 1954 A further examination of the molecular weight and size of desoxy pentose nucleic acid J. Am. Chem. Soc. 76 3047

35. Wolfe A, Shimer G H, Meehan T, Wolfe A, Shimer G H and Meehan T 1987 Polycyclic aromatic hydrocarbons physically intercalate into duplex regions of denatured DNA Biochemistry 266392

36. Maity D, Drew M G B, Godsell J F, Roy S and Mukhopadhyay G 2010 Synthesis and characterization of $\mathrm{Cu}(\mathrm{II})$ complexes of tetradentate and tridentate symmetrical Schiff base ligands involving $o$-phenelenediamine, salicylaldehyde and diacetylmonoxime Trans. Met. Chem. 35197

37. Bhunora S, Mugo J, Bhaw-Luximon A, Mapolie S, Van Wyk J, Darkwa J and Nordlander E 2011 The use of $\mathrm{Cu}$ and $\mathrm{Zn}$ salicylaldimine complexes as catalyst precursors in ring opening polymerization of lactides: Ligand effects on polymer characteristics Appl. Organomet. Chem. 25133

38. Saydam S and Yilmaz E 2006 Synthesis, characterization and thermal behavior of 4-chloromethyl-2-(2hydroxybenzilidenehydrazino) thiazole and its complexes with $\mathrm{Cr}(\mathrm{III}), \mathrm{Co}(\mathrm{II}), \mathrm{Ni}(\mathrm{II})$ and $\mathrm{Cu}(\mathrm{II})$ Spectro. Chim. Acta A 63506

39. Nakamoto K 1997 Infrared and Raman Spectra of Inorganic and Coordination Compounds $5^{\text {th }}$ ed. (New York: Wiley-Interscience) 
40. Bellamy L J 1980 The Infrared Spectra of Complex Molecules $2^{\text {nd }}$ ed. (London: Chapmann and Hall)

41. Rahaman A, Imatiyaz Y, Afazal M, Srivastva S, Saikrishna $S$ and Farukh 2015 Enantiomeric fluoro-substituted benzothiazole Schiff base-valine $\mathrm{Cu}(\mathrm{II}) / \mathrm{Zn}$ (II) complexes as chemotherapeutic agents: DNA binding profile, cleavage activity, MTT assay and cell imaging studies $J$. Photochem. Photobiol. B 14361

42. Takjoo R and Centore R 2013 Synthesis, X-ray structure, spectroscopic properties and DFT studies of some dithiocarbazate complexes of nickel(II) J. Mol. Struct. 1031 180

43. Lever A B P 1984 Inorganic Electronic Spectroscopy 2nd edn. (Amsterdam: Elsevier)

44. Shakir M, Summaiya H, Sherwani M A, Mohammad O and Al-Resayes S R 2015 Pharmacologically significant complexes of $\mathrm{Mn}(\mathrm{II}), \mathrm{Co}(\mathrm{II}), \mathrm{Ni}(\mathrm{II}), \mathrm{Cu}(\mathrm{II})$ and $\mathrm{Zn}(\mathrm{II})$ of novel Schiff base ligand, (E)-N-(furan-2-yl methylene) quinolin-8-amine: synthesis, spectral, XRD, SEM, antimicrobial, antioxidant and in vitro cytotoxic studies J. Mol. Struct. 1092143

45. Shakir M, Abbasi A, Faraz M and Sherwani 2015 A Synthesis, characterization and cytotoxicity of rare earth metal ion complexes of N,Nbis-(2-thiophenecarboxaldimine)-3,30- diaminobenzidene, Schiff base ligand J. Mol. Struct. 1102 108

46. Hathaway B J and Billing D E 1970 The electronic properties and stereochemistry of mono-nuclear complexes of the copper (II) ion Coord. Chem. Rev. 5143

47. Kivelson D and Neiman R 1961 ESR studies on the bonding in copper complexes J. Chem. Phys.35 149

48. Tan L F, Chen X J, Shen J L and Liang X L 2009 Synthesis, DNA-binding and photocleavage studies of $\mathrm{Ru}(\mathrm{II})$ complexes of phenyl-(4,5,9,14-tetraazabenzo[b]triphenylen-1,1-yl)-methanone J. Chem. Sci. 121397

49. Tejaswi S, Kumar M P and Rambabu A et. al 2016 Synthesis, structural, DNA binding and cleavage studies of $\mathrm{Cu}(\mathrm{II})$ complexes containing benzothiazole cored Schiff bases J. Fluoresc. 262151

50. Pyle A M, Rehmann J P, Meshoyrer R, Kumar C V and Turro N J 1989 Mixed-ligand complexes of ruthenium(II): factors governing binding to DNA J. Am. Chem. Soc. 1113053
51. Mondal B, Sen B and Sarkar S et al. 2017 Synthesis, characterization, crystal structure and DNA-binding study of four cadmium(II) pyridine-carboxamide complexes J. Chem. Sci. 12945

52. Kumar M P, Vamsikrishna N, Ramesh G, Subhashini N J P, Jagadeesh B N and Shivaraj 2017 Cu(II) complexes with 4-amino-3, 5-dimethyl isoxazole and substituted aromatic aldehyde Schiff bases: synthesis, crystal structure antimicrobial activity, DNA binding and cleavage studies J. Coord. Chem. doi:10.1080/00958972.2017. 1292503

53. Selvarani V, Annaraj B, Neelakantan M A, Sundaramoorthy S and Velmurugan S 2013 Synthesis, characterization and crystal structures of copper(II) and nickel(II) complexes of propargyl arm containing N2O2 ligands: antimicrobial activity and DNA binding Polyhedron $\mathbf{5 4} 74$

54. Chen J, Wang X, Chao Y, Zhu J H, Zhu Y G, Li Y Z, Xu Q and Guo Z J 2007 A Tri nuclear Copper(II) Complex of 2,4,6-Tris(di-2-pyridylamine)-1,3,5triazine shows prominent DNA cleavage activity Inorg. Chem. 463306

55. Chaires J B 1997 Energetics of drug-DNA interactions Biopolymer 44201

56. Shahabadi N, Fili M S and Shahlaei M 2015 Synthesis, characterization and comparative DNA interaction studies of new copper(II) and nickel(II) complexes containing mesalamine drug using molecular modeling and multispectroscopic methods J. Coord. Chem. 683667

57. Gultneh Y, Khan A R, Blaise D, Chaudhry S, Ahvazi B, Marvey B B and Butcher R J 1999 Syntheses and structures of and catalysis of hydrolysis by $\mathrm{Zn}$ (II) complexes of chelating pyridyl donor ligands Inorg. Bio. Chem. 75 7

58. Armstrong W H and Lippard S J 1984 Reversible protonation of the Oxo bridge in a hemerythrin model compound. Synthesis, structure, and properties of (pHydroxo)bis(p-acetate)- bis[hydrotris(1pyrazolyl) borato]diiron(III), [(HB(PZ)3)WOH) (02CCH3)2Fe(HB(pz)3)1 $1^{+}$J. Am. Chem. Soc. 106 4632

59. Tweedy B G 1964 Plant extracts with metal ions as potential antimicrobial agents Phytopathology 55910 